\title{
PENGARUH PEMBERIAN PUPUK CAIR LIMBAH IKAN LEMURU (Sardinella sp.) DENGAN DOSIS YANG BERBEDA TERHADAP PERTUMBUHAN Chlorella sp.
}

\section{EFFECT OF LIQUIT FERTILIZER WASTE SARDINELLA FISH (Sardinella sp.) WITH DIFFERENT DOSES TO THE Chlorella sp. GROWTH}

\author{
Diana Meritasari, A. Shofy Mubarok, Laksmi Sulmartiwi dan Endang Dewi Masithah \\ Fakultas Perikanan dan Kelautan Universitas Airlangga \\ Kampus C Mulyorejo - Surabaya, 60115 Telp. 031-5911451
}

\begin{abstract}
Chlorella sp. can growth in various media that contains enough nutrients, such as N, P, K and other micro-elements. Growth of Chlorella sp. requires the availability of nutrients that can be derived from the chemical decomposition and solution results or waste. Liquid fertilizer waste sardinella fish (Sardinella sp.) is wasted and without any economic value is a new breakthrough in utilizing any part in the fisheries sector so as to maximize the potential of fisheries. Utilization of this, one of which is to make Liquid fertilizer waste sardinella fish (Sardinella sp.) which serve as nutrients for the growth of Chlorella sp. with 7 treatments and repeated 3 times. The treatment used is the doses of liquid fertilizer waste sardinella fish (Sardinella sp.) differently, namely A (0,25 ml/L), B (0,5 ml/L), C (1,75 ml/L), D (1 ml/L), $\mathrm{E}(1,25 \mathrm{ml} / \mathrm{L}), \mathrm{F}(1,5 \mathrm{ml} / \mathrm{L}), \mathrm{G}$ (Walne), $\mathrm{H}$ (without fertilizer). The results showed that the addition of liquid fertilizer waste sardinella fish (Sardinella $\mathrm{sp}$.) with different doses give a real impact $(\mathrm{p}<0,05)$ for growth population of Chlorella $\mathrm{sp}$. The best doses of liquid fertilizer waste sardinella fish (Sardinella sp.) for the population growth rate of Chlorella sp. was $0.75 \mathrm{ml} / \mathrm{L}$ is the treatment of $\mathrm{C}$ with the highest population of $3500 \times 103$ cells / ml.
\end{abstract}

Keywords : Liquid fertilizer waste sardinella fish (Sardinella sp.), Chlorella sp Growth

\section{Pendahuluan}

Pembenihan merupakan titik awal dalam usaha pengembangan usaha budidaya karena usaha ini berkaitan erat dengan ketersediaan faktor produksi yang memegang peranan kunci agar usaha budidaya dapat berjalan. Salah satu kendala yang dirasakan cukup serius untuk mengatasi masalah mortalitas larva ikan adalah kurangnya ketersediaan pakan alami, baik dalam jumlah maupun mutunya (jenis, ukuran, nilai gizi dan kecocokan bagi kultivan). Dalam budidaya terutama dalam usaha pembenihan, pakan alami merupakan salah satu faktor pembatas (Chilmawati,2008).

Chlorella sp. telah digunakan secara luas terutama di panti-panti pembenihan ikan, udang, kerang-kerangan atau hewan budidaya lainnya. Seperti phytoplankton pada umumnya, Chlorella sp. juga membutuhkan unsur makro N dan $\mathrm{P}$ untuk meningkatkan laju pertumbuhan (Ukeles, 1971). Pertumbuhan Chlorella sp. sangat dipengaruhi oleh beberapa faktor lingkungan, diantaranya unsur hara dalam media kultur serta kualitas air seperti salinitas, $\mathrm{pH}$, suhu, intensitas cahaya yang optimum (Hama, 1988). Untuk mendapatkan persediaan Chlorella sp. sebagai pakan alami, maka diperlukan suatu studi tentang penggunaan media kultur yang memberikan hasil terbaik terutama mengenai jumlah sel atau kepadatan Chlorella sp. yang dihasilkan. Penumbuhan Chlorella sp. memerlukan ketersediaan unsur hara yang dapat berasal dari bahan kimia maupun larutan hasil pembusukan atau limbah (Handajani, 2006).

Limbah pada dasarnya adalah suatu bahan yang terbuang atau dibuang dari suatu sumber aktifitas manusia, maupun proses alam dan tidak atau belum mempunyai nilai ekonomi, bahkan dapat mempunyai nilai ekonomi negatif karena penanganan untuk membuang atau membersihkan memerlukan biaya yang cukup besar disamping itu dapat mencemari lingkungan. Limbah perikanan dapat berupa ikan yang terbuang, tercecer, dan sisa olahan yang menghasilkan cairan dan pemotongan, pencucian dan pengolahan produk (Jenie dan Rahayu, 1990). Pemanfaatan ini, salah satunya adalah menjadikan pupuk cair organik limbah Ikan Lemuru (Sardinella sp.) (Handoko, 2009). Pupuk cair limbah Ikan Lemuru (Sardinella sp.) memiliki kandungan mineral makro seperti Nitrogen (N) $21 \mathrm{~g} / \mathrm{L}$, fosfor (P) 7,3 g/L dan kalium (K) $13 \mathrm{~g} / \mathrm{L}$. Sedangkan kandungan mineral mikro pada pupuk ini adalah kalsium 
(Ca) sebesar 1,4 g/L, magnesium $(\mathrm{Mg})$ 0,13 g/L, tembaga $(\mathrm{Cu}) \quad 0,00017 \mathrm{~g} / \mathrm{L}$, mangan $(\mathrm{Mn})$ $0,0014 \mathrm{~g} / \mathrm{L}$, chlorin $(\mathrm{Cl})$ 0,62 g/L (Sjaifullah, 2008). Penambahan pupuk cair limbah Ikan Lemuru (Sardinella sp.) sebagai nutrien yang merupakan salah satu faktor utama untuk pertumbuhan Chlorella sp. diharapkan dapat meningkatkan populasi Chlorella $\mathrm{sp}$.

\section{Metodologi}

Waktu dan Tempat Pelaksanaan

Penelitian dilaksanakan di Laboratorium Fakultas Perikanan dan Kelautan Universitas Airlangga pada bulan Agustus-September 2011.

\section{Alat Penelitian}

Peralatan yang digunakan dalam penelitian ini, meliputi : Toples kaca sebanyak 21 buah untuk tempat kultur Chlorella sp., aerator, selang aerasi, batu aerasi, pipet volume, pipet tetes, gelas ukur, termometer air, kertas $\mathrm{pH}$, refrakometer, lampu TL, mikroskop, cover glass, haemocytometer, autoklave, lux meter, timbangan digital analitik, kapas, gabus, corong air, kasa, tisue, aluminium foil dan kertas saring.

\section{Bahan Penelitian}

Bahan yang diperlukan, yaitu strain Chlorella sp, pupuk organik cair limbah Ikan Lemuru (Sardinella sp.) yang diperoleh dari Lab Kimia Universitas Jember, pupuk Walne, air laut, air tawar, aquades, alkohol, khlorin.

\section{Persiapan Peralatan Penelitian}

Kawachi and Noel (2005) menyatakan pada dasarnya persiapan untuk kultur berbagai jenis fitoplankton adalah sama, yaitu sterilisasi alat dan bahan yang bertujuan untuk membunuh mikroorganisme yang tidak diinginkan. Untuk perangkat yang terbuat dari kaca disterilkan dengan autoklaf. Sebelumnya peralatan kaca dicuci bersih dengan menggunakan detergen, kemudian ditiriskan hingga kering. Setelah kering masing-masing dibungkus dengan alumunium foil, untuk erlenmeyer dan tabung reaksi ditutup dengan kapas dan dibungkus dengan alumunium foil, setelah itu peralatan diatur rapi dalam autoklaf. Autoklaf ditutup rapat dan dioperasikan dengan suhu $121^{\circ} \mathrm{C}$ dan tekanan $1 \mathrm{~atm}$ selama 30 menit (Isnansetyo dan Kurniastuty, 1995). Untuk peralatan yang lebih besar, sterilisasi dilakukan dengan menggunakan klorin atau kaporit. Peralatan sebelumnya dicuci bersih dengan detergen, kemudian direndam dengan kaporit selama 24 jam. Sedangkan untuk peralatan dari kaca yang didalamnya terdapat endapan atau kotoran yang mengkristal dapat dihilangkan dengan memberikan $\mathrm{HCl}$ pekat, kemudian dibilas dengan Na thiosulfat.

Air laut yang digunakan untuk kultur disterilisasi menggunakan larutan khlorin. Air laut terlebih dahulu disaring dengan kapas yang diletakkan dalam corong air, kemudian disterilkan dengan khlorin 60 ppm dan diaerasi selama 24 jam. Khlorin dapat dinetralkan dengan menggunakan $\mathrm{Na}$ Thiosulfat $20 \mathrm{ppm}$. Air laut yang sudah steril disimpan dalam wadah yang tidak tembus cahaya dan tertutup rapat (Satyantini dkk, 2009).

Lingkungan dan Media kultur Chlorella sp.

Lingkungan tumbuh optimal Chlorella sp adalah pada suhu $30^{\circ} \mathrm{C}$, salinitas $30 \mathrm{ppt}$, pH 7 dan intensitas cahaya 500-1000 lux (Martosudarno, 1990). Media kultur yang digunakan dalam penelitian adalah air laut dengan salinitas $30 \mathrm{ppt}$ sebanyak 0,5 liter yang dimasukkan dalam toples kaca kemudian ditambahkan pupuk cair limbah ikan sesuai dengan konsentrasi yang ditentukan. Selanjutnya, media kultur diletakan di rak kultur kemudian diberikan aerasi dan siap dimasukkan bibit Chlorella sp. dengan kepadatan yang diinginkan yaitu $330 \times 10^{3} \mathrm{sel} / \mathrm{ml}$.

Persiapan Pupuk Cair Limbah Ikan Lemuru (Sardinella sp.) dan Bibit Chlorella sp.

Pupuk Cair Limbah Ikan Lemuru (Sardinella sp.) diperoleh dari Lab Kimia Fakultas MIPA Universitas Jember. Nama pupuk ini adalah "Pupuk Hidrolisat Ikan".Pupuk ini sangat pekat sehingga sebelum digunakan terlabih dahulu disaring untuk memperoleh pupuk yang lebih encer dan menghindari kontaminasi.

Chlorella sp. diperoleh dari Balai Besar Pengembangan Budidaya Air Payau Jepara. Media kultur bibit Chlorella sp. dimasukkan ke dalam toples kepadatan $330 \times 10^{3} \mathrm{sel} / \mathrm{ml}$ (Brautovic, 2000).

Perhitungan Pertumbuhan Populasi Chlorella sp.

Penelitian kali ini penghitungan jumlah kepadatan plankton menggunakan metode "Small Block" karena ukuran sel phytoplankton kecil. Penghitungan kepadatan phytoplankton (sel/ml) dengan menggunakan Persamaan 4. perhitungan "Small Block" (Satyantini dkk, 2009).

Kepadatan phytoplankton $(\mathrm{sel} / \mathrm{ml})=$

$$
\frac{n a+n b+n c+n d+n e}{5 \times 4 \times 10^{-6}}
$$




\section{Hasil dan Pembahasan}

Hasil pengamatan penelitian berupa data pertumbuhan populasi Chlorella sp.. Hasil tersebut digunakan untuk mengetahui pengaruh pemberian pupuk cair limbah Ikan Lemuru (Sardinella sp.) sebagai nutrien dengan dosis berbeda yang dapat menghasilkan pertumbuhan populasi Chlorella sp. tertinggi.

\section{Populasi Chlorella sp.}

Hasil uji jarak berganda Duncan menunjukkan bahwa populasi tertinggi pada hari pertama pada perlakuan $\mathrm{C}$ yang tidak berbeda nyata $(p>0,05)$ dengan perlakuan $D, E$, $F, G$ namun berbeda nyata $(p<0,05)$ dengan perlakuan B, A, H dan, tertinggi pada perlakuan C dan terendah pada perlakuan H. Populasi tertinggi pada hari kedua menunjukkan bahwa perlakuan $C$ yang tidak berbeda nyata $(p>0,05)$ dengan B, A, D, E, F, G, namun berbeda nyata $(\mathrm{p}<0,05)$ dengan perlakuan $\mathrm{H}$ dan tertinggi pada perlakuan $\mathrm{C}$ dan terendah pada perlakuan $\mathrm{H}$.

Populasi tertinggi pada hari ketiga menunjukkan bahwa perlakuan $\mathrm{C}$ yang tidak berbeda nyata $(p>0,05)$ dengan perlakuan $D, F$, $\mathrm{G}$, namun berbeda nyata $(\mathrm{p}<0,05)$ dengan perlakuan $\mathrm{A}, \mathrm{B}, \mathrm{E}, \mathrm{H}$ dan tertingi pada perlakuan $\mathrm{C}$ dan terendah pada perlakuan $\mathrm{H}$. Populasi tertinggi pada hari keempat menunjukkan bahwa perlakuan $\mathrm{C}$ yang berbeda nyata $(\mathrm{p}<0,05)$ dengan semua perlakuan, tertinggi pada perlakuan $\mathrm{C}$ dan terendah pada perlakuan $\mathrm{H}$. Populasi tertinggi pada hari kelima menunjukkan perlakuan $\mathrm{C}$ yang tidak berbeda nyata $(p>0,25)$ dengan perlakuan $G$, namun berbeda nyata $(\mathrm{p}<0,05)$ dengan perlakuan $\mathrm{A}, \mathrm{B}$, $\mathrm{D}, \mathrm{E}, \mathrm{F}, \mathrm{H}$ dan tertinggi pada perlakuan $\mathrm{C}$ dan terendah pada $\mathrm{H}$. Populasi tertinggi pada hari keenam menunjukkan perlakuan $\mathrm{C}$ berbeda nyata $(p<0,05)$ dengan semua perlakuan, tertinggi pada perlakuan $\mathrm{C}$ dan terendah pada perlakuan $\mathrm{H}$.

Populasi tertinggi pada hari ketujuh menunjukkan perlakuan $\mathrm{C}$ yang tidak berbeda nyata $(p>0,25)$ dengan perlakuan $G$, namun berbeda nyata $(\mathrm{p}<0,05)$ dengan perlakuan $A, B$, $\mathrm{D}, \mathrm{E}, \mathrm{F}, \mathrm{H}$, tertinggi pada perlakuan $\mathrm{C}$ dan terendah pada $\mathrm{H}$. Populasi tertinggi pada hari kedelapan menunjukkan perlakuan $\mathrm{C}$ yang tidak berbeda nyata $(p>0,25)$ dengan perlakuan $D, G$, namun berbeda nyata $(\mathrm{p}<0,05)$ dengan perlakuan A, B, E, F, H tertinggi pada perlakuan $\mathrm{C}$ dan terendah pada perlakuan $\mathrm{H}$.

\section{Kualitas Air}

Pengukuran kualitas air laut meliputi salinitas, suhu dan $\mathrm{pH}$ yang diukur setiap hari selama penelitian. Pengukuran $\mathrm{pH}$ dan suhu dilakukan 2x sehari pagi dan sore hari sedangkan untuk salinitas diukur $1 \mathrm{x}$ sehari. Hasil pengukuran kualitas tersebut dapat dilihat pada Tabel 2.

Tabel 2. Kisaran Kualitas Air Selama Hari Pertama Sampai Hari Kedelapan.

\begin{tabular}{|c|c|}
\hline Parameter Kualitas Air & Hasil \\
\hline Suhu & \\
\hline Pagi & $30-32^{\circ} \mathrm{C}$ \\
\hline Sore & $29-31{ }^{\circ} \mathrm{C}$ \\
\hline $\mathrm{pH}$ & \\
\hline Pagi & $7-8$ \\
\hline Sore & $7-7,5$ \\
\hline Salinitas & $30-38 \mathrm{ppt}$ \\
\hline
\end{tabular}

Peningkatan petumbuhan populasi Chlorella sp. yang menggunakan pupuk cair limbah Ikan Lemuru (Sardinella sp.) lebih baik dibandingkan pupuk Walne sebagai kontrol dibanding dengan pupuk Walne. cair limbah Ikan Lemuru (Sardinella sp.) ini memiliki kandungan nitrogen $0,21 \mathrm{~g} / \mathrm{L}$ dan kandungan

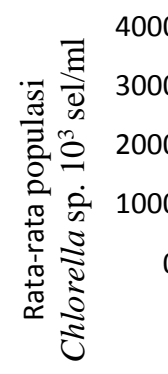
A dosis $0,25 \mathrm{ml} / \mathrm{L}$
$B$ dosis $0,5 \mathrm{ml} / \mathrm{L}$
$\mathrm{C}$ dosis $0,75 \mathrm{ml} / \mathrm{L}$
D dosis $1 \mathrm{ml} / \mathrm{L}$
E dosis $1,25 \mathrm{ml} / \mathrm{L}$
$\mathrm{F}$ dosis $1,5 \mathrm{ml} / \mathrm{L}$
$\mathrm{G}$ kontol walne

Hari ke-

Gambar 7. Grafik Rata-Rata Pertumbuhan Populasi Chlorella sp. dengan Pupuk Cair Limbah Ikan Lemuru (Sardinella sp) Hari Pertama Hingga Hari Kedelapan. 
nitrogen Walne sebesar 0,0169 g/L. Sedangkan kebutuhan nitrogen dalam Chlorella sp adalah 0,14-0,7 g/L (Eyster, 1967), dengan kandungan pupuk $0,21 \mathrm{~g} / \mathrm{L}$ tersebut dapat memenuhi kebutuhan nitrogen dalam tubuh Chlorella sp. Kandungan fosfor pada Pupuk cair limbah Ikan Lemuru (Sardinella sp.) sebesar 0,073 g/L dan kandungan fosfor Walne sebesar 0,004 g/L. Sedangkan kebutuhan Fosfor untuk Chlorella sp. dalam kultur sebanyak 0,0075-0,3 g/L (Eyster, 1967). Dari kandungan fosfor tersebut pupuk cair limbah Ikan Lemuru (Sardinella sp.) dapat memenuhi kebutuhan fosfor Chlorella sp. Kandungan kalium pada Pupuk cair limbah Ikan Lemuru (Sardinella sp.) sebesar 0,13 g/L. Unsur ini dibutuhkan Chlorella sp. sebanyak 0,0095-1,9 g/L (Eyster, 1967), sehingga kebutuhan kalium dalam Chlorella sp. dapat terpenuhi.

Besarnya kepadatan populasi Chlorella sp pada perlakuan C dikarenakan dosis pupuk cair limbah Ikan Lemuru (Sardinella sp.) yang diberikan dalam jumlah yang cukup yaitu sebesar $0,75 \mathrm{ml} / \mathrm{L}$ dengan kandungan nitrogenya sebesar $0,28 \mathrm{gr} / \mathrm{L}$, fosfor sebesar $0,17 \mathrm{gr} / \mathrm{L}$ dan kalium sebesar 0,097 gr/L sehingga Chlorella sp. dapat memanfaatkan nutrien lebih efektif karena sesuai dengan konsentrasi nitrogen optimum untuk Chlorella sp. terdapat pada kisaran 0,14-0,7 g/L, Fosfor (P) 0,0075-0,3 g/L, Kalium (K) 0,0075-1,5 g/L. (Eyster, 1967). Untuk perlakuan $\mathrm{G}, \mathrm{D}, \mathrm{E}, \mathrm{F}, \mathrm{B}, \mathrm{A}, \mathrm{H}$ kepadatannya secara berturut-turut lebih rendah dari perlakuan $\mathrm{C}$, dikarenakan semakin tinggi dosis pemberian pupuk cair limbah Ikan Lemuru (Sardinella sp.) maka efektivitas pemanfaatan nutrien semakin rendah. Apabila nutrien diberikan pada media kultur dalam jumlah berlebih maka bersifat racun yang dapat menghambat pertumbuhan (Hastuti, 2001).

Perlakuan $\mathrm{C}$ memiliki jumlah populasi sel tertinggi yaitu $3.500 \times 10^{3} \mathrm{sel} / \mathrm{ml}$, diduga karena konsentrasi $\mathrm{N}$ dalam $\mathrm{NH}_{3}$ yang tinggi pada media pupuk cair limbah Ikan Lemuru (Sardinella sp.) membuat aktivitas metabolisme tetap berlangsung dalam jangka waktu yang optimum, hal ini menyebabkan pembelahan sel masih terus berlangsung hingga masa puncak. Tingkat efektivitas pemanfaatan nutrien yang rendah dapat juga disebabkan kondisi media kultur yang semakin keruh akibat penumpukan pupuk cair limbah Ikan Lemuru (Sardinella sp). Kepadatan terendah terjadi pada perlakuan $\mathrm{H}$ sebab media kulturnya tanpa pemberian pupuk cair limbah Ikan Lemuru (Sardinella sp) sehingga tidak ada nutrien yang bisa dimanfaatkan untuk pertumbuhan.
Penurunan tersebut diduga bahwa nutrien yang berlebih tidak dimanfaatkan secara efektif sehingga akan menghasilkan tumpukan bahan organik yang bersifat racun dan pada akhirnya dapat menghambat pertumbuhan. Jika nutrien diberikan pada media kultur dalam jumlah berlebih maka bersifat racun yang dapat menghambat pertumbuhan, karena dengan adanya sifat racun maka efektivitas metabolisme sel secara langsung akan terganggu (Hastuti, 2001). Semakin tinggi dosis pupuk cair limbah Ikan Lemuru (Sardinella sp) yang diberikan maka tingkat kekeruhan juga semakin tinggi, sehingga phospat semakin tidak termanfaatkan (Subarijanti, 1994).

Pertumbuhan Chlorella sp. yang dikultur terdiri dari 4 fase yaitu fase adaptasi, eksponensial, stasioner dan kematian. Hasil penelitian pada hari pemasukan inokulan dan hari pertama pengamatan menunjukkan bahwa Chlorella sp. mengalami fase adaptasi pengamatan hari ke-1, unsur nutrien diduga tersedia cukup banyak sehingga pertumbuhan Chlorella sp. dapat cepat terjadi. Richmond (1986) menyatakan bahwa ketersedian sumber unsur nutrien mempengaruhi pertumbuhan Chlorella sp. Pada fase ini ukuran sel meningkat, fitoplankton menjadi aktif dan terjadi sintesis protein. Organisme mengalami metabolisme tetapi belum mengalami pembelahan (Isnansetyo dan Kurniastuty, 1995).

Fase selanjutnya adalah fase eksponensial mulai hari kedua hingga hari keenam pada perlakuan A, B, E, F, H sedangan fase eksponensia pada hari kedua hingga hari ketujuh terjadi pada perlakuan C, G, D. Puncak populasi tertinggi pada hari ketujuh pada perlakuan $\mathrm{C}$ dengan kepadatan $3.500 \times 10^{3}$ $\mathrm{sel} / \mathrm{ml}$. Penambahan dosis pupuk cair limbah Ikan Lemuru (Sardinella sp.) diatas dan dibawah dari $0,75 \mathrm{ml} / \mathrm{L}$, menyebabkan populasi Chlorella sp. mengalami penurunan. Menurut Richmond (1986) dalam Kurniasih (2001), nitrogen yang berlebih justru dapat menghambat proses biosintesis sel alga sehingga produksi RNA dan DNA terhambat.

Waktu pencapaian puncak yang berbeda-beda disebabkan oleh perbedaan konsentrasi dosis pupuk cair limbah Ikan Lemuru (Sardinella sp.) pada media. Menurut Sjaifullah (2008), pada pupuk cair limbah Ikan Lemuru (Sardinella sp.) selain mengandung unsur makro juga mengandung unsur mikro yaitu kalsium (Ca) sebesar 0,014 g/L, magnesium $(\mathrm{Mg}) \quad 0,0013 \mathrm{~g} / \mathrm{L}$, tembaga $(\mathrm{Cu})$ $0,0000017 \mathrm{~g} / \mathrm{L}$, mangan $(\mathrm{Mn})$ 0,000014 g/L, sulfat (SO4) 0,31 $\mathrm{g} / \mathrm{L}$ dan besi (Zn) 0,00005 $\mathrm{g} / \mathrm{L}$. Menurut data dari United State 
Environmetal Agency (USEPA) dalam Bakhtiar (2007), tergolong logam berat berbahaya karena, memiliki sifat toksisitas (racun) yang menurunkan pertumbuhan plankton, walaupun pada konsentrasi yang rendah dan dapat terakumulasi dalam jangka waktu tertentu. Dengan adanya kandungan logam berat dalam pupuk cair limbah Ikan Lemuru ( Sardinella sp.), maka dapat menyebabkan turunnya populasi Chlorella sp. Nutrien yang berlebih tidak dapat dimanfaatkan secara efektif sehingga akan menghasilkan tumpukan bahan organik yang bersifat racun maka efektivitas metabolisme sel secara langsung akan terganggu dan pada akhirnya dapat menghambat pertumbuhan (Handajani, 2010).

Perbedaan kepadatan populasi tersebut disebabkan adanya kemampuan sel dalam memanfaatkan nutrien untuk pertumbuhannya. Fase eksponensial yang terjadi pada penelitian kali ini tidak sesuai dengan pendapat Chilmawat (2008), yang berpendapat bahwa Fase eksponensial pada kultur Chlorella sp. adalah pada hari ke 2-5 Pada puncak fase eksponensial ini, dapat dilakukan pemanenan Chlorella sp. karena populasinya tertinggi dibandingkan pada waktu fase pertumbuhan lainnya (Rusyani dkk., 2007). Terhentinya fase eksponensial menurut Fogg (1965), disebabkan berkurangnya nutrien. Jumlah nutrien yang semakin berkurang dengan meningkatnya jumlah populasi. Pada pelakuan C kelimpahan puncak sangat tinggi, hal ini sangat menguntungkan bagi kultur pakan alami yang membutuhkan jumlah pakan yang cukup.

Fase stasioner terjadi dalam waktu singkat, sehingga tidak nampaknya fase stasioner pada setiap perlakuan. Fase stasioner terjadi karena nutrien dalam media sudah sangat berkurang sehingga tidak mencukupi untuk pertumbuhan dan pembelahan sel (Prihantini, 2005). Setelah mencapai puncak sebelum fase kematian kepadatan akan cenderung relatif tetap, walaupun terjadi penurunan tidak akan begitu besar, tetapi pada penelitian ini setelah mencapai puncak kepadatan sel tiap perlakuan cenderung untuk langsung menurun. Fase kematian terjadi setelah masing-masing perlakuan media mencapai puncak populasi, pada perlakuan A, B, E, F, H terjadi pada hari ketujuh sedangkan perlakuan $\mathrm{C}, \mathrm{G}, \mathrm{D}$ terjadi pada hari kedelapan. Pengurangan populasi ini disebabkan karena kultur yang dilakukan pada volume yang terbatas yang menyebabkan jumlah nutrien yang terkandung dalam media juga terbatas sehingga Chlorella sp. tidak mampu lagi mempertahankan kepadatannya (Chilawati, 2008).
Faktor pendukung dalam pertumbuhan populasi Chlorella sp selain dipengaruhi oleh kandungan nutrisi juga dipengaruhi oleh kualitas air. Hasil pengukuran suhu air pagi selama penelitian berkisar antara $30-32^{\circ} \mathrm{C}$ dan suhu air sore berkisar antara $29-31^{\circ} \mathrm{C}$. Menurut Kinne (1970) suhu rata-rata berkisar $20^{\circ} \mathrm{C}$ sampai $30^{\circ} \mathrm{C}$. Suhu air mempunyai pengaruh yang besar terhadap proses metabolisme (Suriawiria, 1985). Pada penelitian ini nilai $\mathrm{pH}$ pagi berkisar antara 7-8 dan nilai $\mathrm{pH}$ sore berkisar antara 7-7,5. Nilai $\mathrm{pH}$ optium untuk kultur Chlorella sp. berkisar antara 7-9 (Effendi, 2003), jadi pH dalam penelitian ini masih dalam batas optium. Salinitas pada penelitian ini berkisar antara 30-38 ppt. Kisaran tersebut termasuk tinggi karena terjadi penguapan dan tidak ada penambahan air mengakibatkan salinitas tinggi. Salinitas yang ada pada penelitian tidak sesuai dengan pendapat Converti (2009) yang menyatakan bahwa salinitas optimum untuk pertumbuhan Chlorella sp. berkisar antara 30-32 ppt. Darley (1982) menyatakan, salinitas sangat berpengaruh terhadap pertumbuhan sebab berhubungan dengan aktifitas osmosis sel. Semakin tinggi tekanan osmotiknya maka salinitas suatu perairan akan semakin tinggi pula.pertumbuhan Chlorella sp. menurun sejalan dengan naiknya salinitas dari 40-60 ppt. Menurut Nakanishi dan Monshi (1965) mengatakan bahwa naiknya salinitas berpengaruh baik terhadap fotosintesis maupun respirasi, yang mana salinitas berpengaruh lebih besar terhadap fotosintesis daripada terhadap respirasi. Dengan kualitas air saat penelitian masih bisa dilakukan kultur Chlorella sp.

\section{Kesimpulan}

Berdasarkan hasil penelitian yang telah dilaksanakan, maka dapat disimpulkan sebagai berikut : Pemberian pupuk cair limbah Ikan Lemuru (Sardinella sp.) dengan dosis berbeda memberikan pengaruh berbeda sangat nyata $(\mathrm{P}<0,05)$ terhadap laju pertumbuhan populasi Chlorella sp. Dosis pemberian pupuk cair limbah Ikan Lemuru (Sardinella sp.) yang terbaik untuk laju pertumbuhan populasi Chlorella sp. adalah $0,75 \mathrm{ml} / \mathrm{L}$ yaitu pada perlakuan $\mathrm{C}$ dengan jumlah populasi tertinggi $3500 \times 10^{3} \mathrm{sel} / \mathrm{ml}$ pada hari ke-7.

Pertumbuhan populasi Chlorella sp. yang dikultur pada media pupuk cair limbah Ikan Lemuru (Sardinella sp.) maka dosis yang dipakai adalah $0,75 \mathrm{ml} / \mathrm{L}$. Namun masih perlu dilakukan penelitian lebih lanjut mengenai limbah kultur Chlorella sp. yang dilakukan 
secara massal pada media pupuk cair Ikan Lemuru (Sardinella sp.).

Daftar Pustaka

Chilmawat, D dan Suminto. 2008. Penggunaan Media Kultur Yang Berbeda Terhadap Pertumbuhan Chlorella sp. Program Studi Budidaya Perairan, Jurusan Perikanan Fakultas Perikanan dan Ilmu Kelautan Universitas Diponegoro. Semarang.

Converti A, Casazza, A.A., Ortiz, E.Y., Perego Patrizia, Borghi, M.D. 2009. "Effect of temperature and Nitrogen Consentration on The Growh and lipd content of Nannochloropsis oculata and Chlorella vulgaris for Biodiesel Production". Chem. Eng. Process.

Darley, W.M. 1982. Algal Biology: a Physiological Approach. Departement of Bontany. The Univercity of Georgia. Blackwell Sientific Publications. Oxford London. Edinburgh Boston Melburne. p. 97-98.

Effendi H. 2003. Telaah Kualitas Air Bagi Pengelolaan Sumberdaya dan Lingkungan Perairan. Yogyakarta.

Eyster, C. 1967. Nutrien Concentration Requirements For Chlorella Sorokikiana. USAF School of Aerospace Medicine, Aerospace Medical Division (AFSC). Brooks Air Force Base, Texas. 186 pp.

Fogg, B. Thake. 1987. Algal Cultures and Phytoplankton Ecology, 3rd ed., The University of Wisconsin Press, Wisconsin.

Hama, O.H. dan S. Miyachi. 1988. Chlorella. Microagae Biotechnology. 1st edition. Cambridge University.

Handajani, H. 2006. Pemanfaatan Limbah Cair Tahu sebagai Pupuk Alternatif pada Kultur Mikroalga Spirullina sp. Jurusan Perikanan Fakultas Peternakan Perikanan Universitas Muhammadiyah. Malang. Hal 189.

Handoko, A. H. 2009. Pemanfaatan Limbah Ikan untuk Pupuk Organik. http: //agrobinautama.blogspot.com/2009/03/p emanfaatan-limbah-ikan-untuk-pupuk .html. 14/04/2011. 3 halJenie, B. S. L., dan W. P. Rahayu.1990. Teknologi Limbah Pangan. Kanisius. Yogyakarta

Isnansetyo, A dan Kurniastuty. 1995. Teknik Kultur Fitoplankton dan Zooplankton. Pakan Alami untuk Pembenihan Organisme Laut. Kanisius. Yogyakarta. 108 hal.
Kinne, O. 1970. A Comprehensive Integrated Treatise Onlife In Oceans And Coastal Water. Marine ecology. Volume 1. Wiley- Interscience. London.

Martosudarmo, B. dan Sabarudin, S. 1979. Makanan Larva Udang . Balai Budidaya Air Payau. Jepara.

Nakanishi, M. and M. Monshi. 1965. Effect of Variation in Salinity on Photosyntesis of Phytoplankton Growing in Esturies. J. Fac. Sci. Tokyo Univercity., (Sec. III). 9 (2): 19-42.

Prihantini, N. B., Putri. B. dan Ratna. Y. 2005. Perumbuhan Chlorella spp. Dalam Medium Ekstrak Tauge (MET) Dengan Variasi pH Awal. Departemen Biologi. Fakultas MIPA. Universitas Indonesia. Depok.

Richmond, A. 1986. CRC Handbook of mikroalga Mass Culture. CRC PressInc. Florida. 468 p.

Rusyani, E., Sapta A.I.M. dan Lydia E., 2007. Budidaya Fitoplankton Skala Laboratorium dalam Budidaya Fitoplankton dan Zooplankton. Balai Budidaya Laut Lampung. Direktorat Jendral Perikanan Budidaya. Departemen Kelautan dan Perikanan: 9. Lampung. hal. 48-59.

Satyantini, W. H., E. D. Masitha., M. A. Alamsjah,. Prayogo,. S. Andriyono. 2009. Penuntun Praktikum Budidaya Pakan Alami. Fakultas Perikanan dan Kelautan. Universitas Airlangga. Hal 49.

Subarijanti, H.U., 1994. Faktor Lingkungan yang Mempengaruhi Pertumbuhan Plankton. Universitas Brawijaya. Malang.

Suriawiria, U. 1985. Pengantar Mikrobiologi Umum. Angkasa. Bandung. 224 hal.Suriawiria, U. 1987. Biomassa Alga Perairan dan Manfaat Chlorella sp.. Kursus Singkat Dasar Teknologi Farmasi. PAU Bioteknologi ITB. Bandung.

Ukeles, R. 1971. Nutritional equirements in shellfish culture In : K. S. Price Price Jr. and D. L. Maurer (Eds). Nutritional equirements in shellfish culture. Proch. Conf. On Artificial Propagation of Commercially Valuable ShellfishOysters. Univ. Delaware, newrk. DE : 22-23 October 1963 : 43-64. 